of literature, it is not so easy to determine the solution of the converse problem. It is not sufficient to let the non-scientist do badly some diluted version of the scientist's course; what is needed, it seemed to Sir Charles, is the philosophical approach, whereby the great steps in the history of science, the modern applications of science, and its future possibilities are all freely discussed. He thought that science teachers tend to like to teach what they know with certainty, and that they are "deeply unwilling to go outside the field of precise knowledge". It is most important that the misunderstandings between scientists and humanists should be recognized as a deep and serious problem of education; it is something that we had even begun to think about it.

The mornings of the three succeeding days were occupied by lectures. These were by Prof. J. G. Wilson on cosmic ray astronomy, by Prof. L. N. Pyrah on scientific methods in urological research, Prof. F. W. Spiers on "Radiation and Man", Prof. J. T. Whetton on science applied to mining problems, Prof. E. A. Spaul on hormones and behaviour, Prof. E. G. Cox on magnetism and chemistry, Dr. F. E. Hoare on low temperatures as a research tool, Dr. Dorothy $H$. Rayner on problems of palæontology and evolution, Prof. R. D. Preston on physics applied to botanical problems, and Prof. J. B. Speakman on the chemical revolution in textile technology. Guest lecturers from outside the University were Mr. A. B. Thompson, of the Imperial Chemical Industries Terylene Council, who dealt with the physico-chemical principles underlying fibre-making processes, and Prof. L. Rosenfeld, of the University of Manchester, who spoke on Hellenistic science; the growth of interest in the history of science was shown by the size and membership of his audience.

The second evening-lecture, held under the auspices of the Science and Civilization Lecture Fund, was given in the Parkinson Hall by Mr. Ritchie Calder, who spoke on "The Presentation of Science to the Public". Mr. Calder dealt first with his own experiences in Israel when he was engaged in making plain to the Israeli public that a costly research institution was an asset to the State, even at a time when the State was fighting for its existence, and when the value of the scientific work undertaken might not have been immediately obvious. He found that the research scientists themselves are all too apt to think that any indulgence in publicity would lead to a lowering of their seientific standards. He went on to give other instances, not in Israel, where famous scientists had to be persuaded that it was very well worth while to give accounts of their work which could be understood by the ordinary newspaper reader.

The afternoons were occupied by visits to university departments and to factories and other works near Leeds; there were twenty-four of these, a record number. On the third evening the University held a reception for the Association; at this some three hundred members and their ladies were welcomed by the Chancellor, H.R.H. The Princess Royal.

An exhibition by publishers, manufacturers, and members occupied a large space in the chemical and physical laboratories; there were also special exhibitions by the Atomic Energy Research Establishment, the Aluminium Development Association, and the Copper Development Association.

A programme of scientific films, rather larger than usual, included one entitled "Galileo's Law of Falling Bodies", made by Encyclopædia Britannica Films, Ltd., in the United States in conjunction with the Ford Foundation; this forms part of a filmed teaching course of physics, which will be obtainable in Britain from the Gaumont British Film Library.

The final morning session ended with a demonstration and a discussion, which, owing to limitations of time, had to be held simultaneously.

The very striking demonstration, entitled "Biology for Non-Biologists", was given by Mr. C. H. Bailey, senior lecturer in science at Didsbury Training College; his experiments were carried out with simple appara. tus and are intended for those teaching in secondary modern schools, where only a minimum of equipment may be available.

The discussion was held by the Association's Science and Religion Group, and was initiated by the Rev. G. W. Burningham, who acts as chaplain to the Anglican students at the University of Leeds. He emphasized how much greater was the interest of students in religion than it was twenty years ago, and that, if anything, the science students were more keen than the others; there is now more realization of the interdependence of scientific discoveries and religious beliefs. The ensuing discussion ranged over such subjects as miracles, the nature of the soul, and definitions of Heaven and of eternal life.

At the business meeting, Sir Lawrence Bragg was elected president for the ensuing year, and $\mathrm{Mr}$. Charles Holt, of Harrow Weald County School, was elected chairman. The treasurer, Mr. S. W. Read, reported a very favourable balance on the year's working ; and it was announced that the next meeting would take place in University College, London, during December 30, 1958-January 2, 1959.

\title{
THE METEOROLOGICAL OFFICE
}

\section{ANNUAL REPORT, 1956-57}

COME years ago a prominent authority was heard $S$ to suggest that the annual report of the Meteorological Office might well provide a splendid subject for discussion at a meeting of the Royal Meteorological Society; for every year it gives food for thought. Englishmen regard the weather as their common property; and informed scientists cannot but admire the determination with which the public service endeavours to remain free from perturbation, whatever difficulties attend their efforts to cope with the vagaries of atmospheric behaviour. The Meteorological Office, in the nature of things, is alweys on guard duty. Day by day its actions, like those of the sentries at Buckingham Palace, are subject to every variety of comment from the bystanders. Fortunately there are always some with enough knowledge to admire a difficult task well done; and to recognize that the demands of a modern community continue to add to the difficulties. Forecasting the winds for a jet bomber at $50,000 \mathrm{ft}$. is a 
requirement far beyond the conceptions of those who, sixty years ago, were willing to estimate in what parts of the country the term 'muggy' might apply, on the assumption that the oncoming depression would resemble Abercromby's classical model.

The annual report of the Meteorological Office for the year ended March 31, 1957*, shows admirably, with a subdued but unmistakable note of confidence, that the public service continues to make that sober progress which is to be desired on the part of those who study turbulent motion. As Sir Graham Sutton says, the meteorological problem is probably the most difficult in classical physics, and progress can only be made with the utmost diligence. Forecasting naturally attracts most attention, and efficient accomplishment in dealing with stupendous quantities of incoming factual material will be greatly aided as newly installed electronic computers come more into use. The development and direction of an active cadre of young research workers will ensure that in an accelerating world we shall not only keep up with our neighbours, but may here and there set the pace.

* Annual Report on the Meteorological Office for the year April 1 1956, to March 31, 1957. Pp. $51+4$ plates, (M.O. 633.) (London H.M. Stationery Office, i957.) 3s. net
Readers of the report cannot fail to be impressed by the variety of services provided and by the diversity of research; for example, "experiments with the release of silver iodide from ground generators on Salisbury Plain continue with no result yet detectable". Elsewhere is mentioned the work on forecasting the outlook for periods up to a month ahead; "the outlook on this stubborn problem is rather brighter than hitherto".

The British business man is too often insufficiently aware of these public services; and the potential rewards of successful forecasting offer abundant temptation to incautious consultants. There are those who, to all appearance, gamble on sunspots ; those who believe it has been given to them to discover periodicities of various sorts ; those who think in terms of singularities, and perhaps some on the outskirts who appear to be best described as 'hunchdrunk', to use the delightful phrase coined by an eminent professional meteorologist. But how many of our would-be 'independent consultants' have the temerity to disregard the world synoptic charts, so efficiently assembled by the Meteorological Office working with other nations in an unostentatious but exhilarating daily display of international collaboration?
Gordon Manley

\section{RÉAUMUR}

$\mathrm{B}$ ESIDES his thermometer, René-Antoine Ferchault, lord of the manor of Réaumur in the Vendée, and of Des Angles and La Bermondière, made many contributions to scientific knowledge. In 1708 , at the age of twenty-five, he presented a memoir to the Academy of Sciences, and in 1709 two others concerned with general solutions of certain gaometrical problems. Having justified his election as élève in geometry, he then turned his attention to natural history, and in some highly original observa tions demonstrated that the shells of molluses grow by successive external additions of new parts rather than by the alternative process of intussusception. On the death of the geometer Louis Carré in 1711, he was promoted to pensionnaire mécanicien and put in charge of the work on trades, arts and crafts ; he compiled volumes on the manufacture of anchors, of pins and of cast iron.

In the next few years Réaumur discovered an insect living as an internal parasite on the snail; he studied the movements of shell-fish, sea-anemones and starfish, and the great variety of organs of locomotion in shell-fish and their means of attachment to different solid bodies; he found a hitherto unknown fish that gave a purple colouring matter like the famous Tyrian purple of the ancient world; he demonstrated the correctness of the popular belief that crayfish, crabs and lobsters, having lost a claw, could grow another in its place; he studied the torpedo fish, or electric ray, known for its property of benumbing the hand or limb that touched it, and, while the usual explanation was that this was due to the emission of 'torporific corpuseles', he argued that it was produced by the speed and rapidity of the blow that the ray could inflict by means of its admirably constructed muscular system; he examined the native turquoises of Languedoc, showed that they were in no way inferior to those imported from Persia, supposed at that time to be the only source of these gems, and demonstrated by experiments that they were petrified fossil-bones coloured by a metallic ingredient dissolved in them by firing; he studied pearls and their production and falsification, considering the former as due to disease and showing that the colouring matter of false pearls was obtained from the scales of a fish known as the ablette (in English, the bleak); he examined the great bank of falun, or fossil shell-marl, in Touraine; he was interested in the nature and formation of flint, in the plant called Nostoc or star-jelly, in the luminescence of certain shell-fish, in the ease of magnetization of iron and steel by percussion, and in the recovery of gold from the sands of various French rivers; he had also already begun to reveal his active interest in the practical arts and their relation to the sciences, reporting to the Academy descriptions of the prepara. tion of slate, and of the gilding of leather, of mining for iron-ore, of the manufacture of mirrors, of the drawing of gold-wire and the properties of paper and other bodies in preventing the passage of air and water.

Later, Réaumur published a paper describing the procedure for the conversion of wrought iron into steel : this is a landmark in the history of the iron and steel industry and effectively marked the introduction of the manufacture of steel into France.

Réaumur also rendered a similar service to the tinplate industry; he showed that vinegar was the cheapest and most effective solvent for the removal of the scale from the surface of the iron before tinning.

All this, as well as Réaumur's outstanding achievements with thermometers and in entomology, is described in a fascinating article by Prof. D. McKie published in Science Progress (45, No. 180 ; 1957). Besides this study of Réaumur, the journal contains an article by Prof. W. B. R. King on water supply and geology and one by Dr. G. H. A. Cole on the Earth and its magnetic field. 